\title{
Productivity of the millennial generation in institutions of higher education
}

\author{
Productividad laboral de la generación millennial en instituciones de educación \\ superior
}

\author{
NAVARRO-HERNANDEZ, Ana Rosa $\uparrow^{*}$ \& CASTRO-VALENCIA, Alberto Merced \\ Universidad Autónoma de Guadalajara. Av. Patria 1201, Lomas del Valle, 45129, Zapopan, Jalisco, Mexico.
}

ID $1^{\text {st }}$ Author: Ana Rosa, Navarro-Hernandez / ORC ID: 0000-0003-3224-1311, Researcher ID: W-3247-2019, CVU CONACYT ID: 960192

ID $1^{\text {st }}$ Coauthor: Alberto Merced, Castro-Valencia / ORC ID: 0000-0001-8160-9077, Researcher ID Thomson: D-34622018, arXiv Author ID: 2776339, PubMed Autor ID: D-3462-2018, CVU CONACYT ID: 222325

DOI: $10.35429 /$ EJRS.2019.9.5.34.43

Received September 10, 2019; Accepted December 21, 2019

\begin{abstract}
General objectives: evaluate the relationship that exists between job satisfaction, organizational climate and leadership within higher education institutions in the Metropolitan Area of Guadalajara. Specific: analyze the relationship between job satisfaction and productivity in the millennial generation (GM), analyze the relationship between the labor climate and productivity (GM) and analyze the relationship between leadership and productivity (GM). Methodology: It is about making a comparison between the generations: millennial (19802000), baby boomers (1945-1965), "X" (1965-1980) and "Z" (2000-present), it is a theoretical support of articles, a quantitative research is carried out, in which up to now the application of 50 instruments has been carried out in a simple random pilot sample which gathered people of all ages who are currently responding at the Autonomous University of Guadalajara. Contributions The theory aims to contribute to the generation of a model on the characteristics that millennials are interested in their work. In the methodological aspect a specific instrument is used for each variable: job satisfaction in Meliá and Peiró (1998), organizational climate of Koys and Decottis (1991), leadership of Bargavi, Paul \& Samuel (2006) and for productivity Sources (2012).
\end{abstract}

Prodcutivity, Labor Satisfaction, Organizational Climate, Leadership

\begin{abstract}
Resumen
Objetivos generales: evaluar la relación que existe entre la satisfacción laboral, el clima organizacional y el liderazgo dentro de las instituciones de educación superior en la Zona Metropolitana de Guadalajara. Específico: analizar la relación entre la satisfacción laboral y la productividad en la generación milenaria (GM), analizar la relación entre el clima laboral y la productividad (GM) y analizar la relación entre liderazgo y productividad (GM). Metodología: Se trata de hacer una comparación entre las generaciones: millennial (1980-2000), baby boomers (1945-1965), "X" (1965-1980) y "Z" (2000-presente), es un apoyo teórico de los artículos, se lleva a cabo una investigación cuantitativa, en la que hasta ahora la la aplicación de 50 instrumentos se ha llevado a cabo en una simple muestra piloto aleatoria que reunió a personas de todas las edades que actualmente están respondiendo en la Universidad Autónoma de Guadalajara. Contribuciones La teoría tiene como objetivo contribuir a la generación de un modelo sobre las características que los millennials están interesados en su trabajo. En el aspecto metodológico se utiliza un instrumento específico para cada variable: satisfacción laboral en Meliá y Peiró (1998), clima organizativo de Koys y Decottis (1991), liderazgo de Bargavi, Paul \& Samuel (2006) y para fuentes de productividad (2012).
\end{abstract}

Productividad, Satisfacción Laboral, Clima Organizacional, Liderazgo

Citation: NAVARRO-HERNANDEZ, Ana Rosa \& CASTRO-VALENCIA, Alberto Merced. Productivity of the millennial generation in institutions of higher education. ECORFAN Journal-Republic of El Salvador. 2019. 5-9: 34-43.

\footnotetext{
* Correspondence to Author (email: amri86@ hotmail.com)

$\dagger$ Researcher contributing first author.
} 


\section{Introduction}

The issue of organizational climate is known and most people talk about it, especially at the managerial level, to define it, several authors are taken into account, who due to their studies make several proposals, for the purpose of this work Salazar is taken, Guerrero, Machado and Cañedo (2009), where it is stated that it is made up of three characteristics: the general ones which deal with the economic, social, legal and technological context that in turn impact the decisions of the managers and executives of the companies, then the operability is observed, in which the client, the work and the suppliers play a very important role to carry out the organizational plans and finally there is the intern which is the totality of the strategies and actions that are takes internally, impact on the direction and performance of all, compared to the previous two, the latter has the characteristic of acting within the organization.

In the relevant characteristics of the organizational climate are the history of the company, that is; since its foundation, the expansion of the same and the criteria they take for the hierarchy of the same, as well as the profile of the people who work in the company, the training that is carried out, the conditions of the hiring package as the benefits, the attitudes and aptitudes of the employee, the technology that is at your disposal among others. The SWOT analysis should be taken into account as a follow-up of the strategies that have been previously implemented, the strengths, weaknesses, threats and opportunities lead to employee safety at least to the sense of security and this is how productivity is intended of the same increase.

However, the issue of productivity is analyzed which involves certain aspects that are implicit in the human being such as: health, wellbeing, happiness, fulfillment of dreams and expectations which are valuable for their work and directly impact on labor productivity, it is said that the motivation that arises from the individual is totally self-directed, that is, the subject exercises it for himself, that is why companies strive to make people productive but the most important factor for this to be achieved is that the same worker decides.

\section{Theoretical framework}

Generations are identified by the year of birth, age, location and events that are characteristic of the formation of his personality, Guha (2010). Generations of people can also be classified by means of events that live in their time, for example: values, expectations, wars, technologies and economic situations (Howe and Vos, 2010), currently the work areas are basically dominated by three generations, which are "baby boomer", "generation $\mathrm{x}$ " and "millennials" (Kafi, Nefi, Khanfar and Kaifi, 2012). Each of the generations is specified below and throughout the reading the various definitions that place people through the ages will be reviewed, the "baby boomer" generation 1943 - 1960 begins, they are called so because of that when men returned from the Second World War, a large number of babies were born at that time and a baby boom was created, at that time the economy was prosperous and with respect to technology the people of these years did not grow with it, therefore the dependence on it would not be the same as today, (Kaifi et. Al, 2012; Smola and Sutton, 2002).

The " $X$ " generation is the people who were born between 1961 and 1979, this generation is defined by the period of decay in the light of the baby boom, that is, the " $\mathrm{X}$ " generation was the first to return home after from school and did not find their parents since they were working outside, the same happened with their breasts since they also went to work, the " $\mathrm{X}$ " generation grew around a divorce, a not very stable economy and high crime ( Cahill and Sedrak, 2012). The generation born between 1980 and 2000, mostly known as Millennials, is called that because of its proximity to the millennium and they are mostly influenced by technology and computer issues, they have a greater acceptance of families and values that are not traditional (Andert, 2011). For greater retention and understanding of the employer with his subordinate, one must take into account what motivates the person and what satisfies him (Guha, 2010), a notable difference in millennials is that they have more confidence in themselves which allows them to move up or develop new forms of work, young millennials have greater assertiveness and a high level of self-esteem compared to other generations when they were the same age, which can also generate greater productivity (Deal, Altman and Rogelberg , 2010). 
Below are the characteristics of which the millennial generation take as an important part to decide to enter or remain in a job:

* Corporate social responsibility:

It is a business vision that integrates respect for people, ethical values, the community and the environment with the management of the company, regardless of the products or services it offers. CEMEFI 2018

* Training and Feedback:

One of the suggested objectives for the achievement of the growth of productivity at work is training, which is a concept of the union of the elements of intrinsic motivation, factors such as decision making, work strategy, theory of social learning and self-management knowledge (Rowlinson, 2007)

\section{* Significant work experience:}

Murray, (2011) mentions that the NET generation (millennials) have perfected the culture in regard to the behaviors they have throughout their lives, whose behaviors are personalization which refers to the identification of the individual and know how to detect their needs, experimentation, empirical learning, quick reward, balance between life and home, high expectations regarding their careers, quality of life and inspiring leadership by their boss.

\section{* Teamwork:}

It has been reviewed that millennium young people adapt better in the form of teamwork and that they have a greater tolerance in the subject of tattoos since they know that there is a diversity of cultures and they know how to respect it (Andert, 2011 and Kaifi et. al, 2012).

\section{* Leadership:}

The leader is the one who leads the team to achieve their goals and their personal skills are valued to the extent that they are useful to the group. The leader is not because of their ability or ability in themselves, but because these characteristics are perceived by the group as necessary to achieve the objective. (Andert 2011).

\section{* Technology:}

In most areas it is identified that recent information technologies, as well as new business strategies, increased employee productivity, globalization among others. (Mazzotti and Constantino, 2010).

\section{* Good pay:}

Salary based on sales or other clear and attainable goals is one of the main reasons for millennials in choosing a place to work (Salonen, S. 2017).

\section{* Opportunity to Advance Fast:}

Twenge and Campbell, (2008) quoted in Ng \& Gossett, (2013) comments that millennials have been living with the belief that they have talent and intelligence to achieve their goals, so they concentrate heavily on their own success. all the time a way of life which has extrinsic rewards, they comment "I want to work for those companies that go beyond just making money".

It is clear that motivation is a key element when it comes to productivity, because this factor is a main issue among people of human resources, the motivating factors influence the desires to perform an activity as well as the extrinsic factors, the way of being able to captivate colleagues with the fact of doing a task well, as well as the relationship between labor activities in general Ryan and Deci, (2000) cited in Ertas, (2015). Administration researchers have not lost sight of human resources management, the relationship between human resources management and the rotation of personnel and productivity, as well as the motivations that exist intrinsically or extrinsically, in this context enters the performance that has been one of the elementary foci in the federal service (Hamilton, 2010).

The axis of rotation of personnel and productivity is known to generate setbacks with regard to the provision of services which can lead to logistics delays or quality problems (Bertelli, 2006). To carry out this study, questionnaires were carried out taking as a reference the survey of "Point of View for Federal Employees", which was carried out electronically in the months of April and May (2011). 
The response rate is reviewed from $49.3 \%$. , in a very differentiated way, the hypothesis is identified, which tries to recognize if it is true that millennilas are prone to warn the intention to leave their jobs, the result is that the probabilities for the young millennium to leave their employment were approximately 5 times more than an older employee with more years in the company, the statistical difference is significant which is accepted the previous hypothesis (Ertas, 2015).

It is interesting to know the expectations of young people who are about to graduate, to know the requirements of what they will ask for in their workplaces, it is important because in this way employers can prepare the land of their companies to receive them, without a doubt The financial situation has high influence at the time of job selection for young millennials which helps to know how to manage the positions in the company, (Howe and Vos, 2010) cited in (Córdova, 2017), employers worry too much in these aspects because a better work harmony creates a better work environment which causes more productivity and is attractive for the millennium generation (Hasluck, 2012).

Armstrong cited in Obisi, Ashuonye, Gbadamosi, \& Aderotimi, (2016) mentions that through experiences and traits, which are less stable, new expectations and ways of understanding life situations can be formed, in this sense It handles a point which is about apathy at work, that is, there is no measurement of the attitude which allows evaluating the productivity of employees, therefore it is an area of opportunity for universities which can contribute with respect to employees with the review and measurement of attitudes and forms of interaction in labor relations, as well as, the union of the group, union with the university and non-academic activities. In the study carried out by Aderotimi (2016), what is attempted is to avoid misunderstandings among the company's employees, as well as frictions, reasons for distractions, quarrels, attempts are made to take or lead to productivity, an effective organization, growth and well-being In general for employees.
In the selected university the diverse cultures were taken into account, which are valuable for the study, some characteristics that may be similar among the employees are those that have a desire for personal dominance, and have influence as leaders in the organization, once again the interest of obtaining promotions within the company, independence as well as high self-esteem for decision making, Roethlis and Simón, (2012) cited in Obisi, Ashuonye, Gbadamosi, \& Aderotimi, (2016) are mentioned. Leaders must preserve prudence in relation to people's attitudes since they change and must be observed carefully all the time, (Satter, 2011) cited in Obisi, Ashuonye, Gbadamosi, \& Aderotimi, (2016), work under the hypothesis that there is no statistical dependence on working conditions and ways of being of employees, in the end the relevance of productivity associated with variables such as punctuality, publications, classification of results over time and The relationship with the elderly, co-workers and students, the elaboration of tasks over time lead to the absence of service messages and a very bad planning of strategic actions. A 5-point Likert scale was used where the very good rating was 5 and very bad 1 , but 240 of the respondents who were extracted from a 1600 population, the selected universities were Business Administration, Engineering, Science Social and Medical Sciences.

If what Armstrong (2012) argues, labor contexts in which there is well-being in general, specify what measure of productivity they have, that is, commitment to duty, work circumstances surround important aspects such as incentives, benefits as well as the attitude of the superiors with the collaborators (Miner and Luchsinger, 1985) cited in Obisi, Ashuonye, Gbadamosi, \& Aderotimi, (2016). If what is required is to increase productivity in the company, it is necessary to have attitudes in the workers which have clear goals in the organization and are aimed at university management (Stevans, Palut and Burks, 2008) cited in Obisi, Ashuonye, Gbadamosi , \& Aderotimi, (2016).

The study cited in Wolke (2015) conducted by Great Smoky Mountain reviews reports related to abuse and intimidation between the ages of 9 and 16, which are the mental situation of adults between 19 and 25 years, it is stated that the exhibition. 
Long term of a rigid environment and of bad treatment present low productivity in general, for which the idea that a healthy context that promotes the well-being of the person translates into productivity is retaken.

According to Osibanjo, Gberevbie, Adeniji, \& Oludayo, (2015) in their study carried out in 2015, the fact that the collaborators of the competent companies retain the correct and necessary indications is observed, so they also have experiences and knowledge which includes financial value in the issue of quality to experience greater productivity in the organization (Rao, 2000). Says McCroskey (2006) "the attitude towards a source of communication that took place at a certain time by a receiver", the above means that the most reliable supervisor is easily recognized by his receivers in this case the people in charge, is assuming that the leader takes into account the objectives of a worthy agent and an administrator who pays a reward for feeling satisfaction in his work with respect to his subordinates. Definitely job satisfaction is essential for high productivity in employees (Osibanjo, Gberevbie, Adeniji, \& Oludayo, 2015).

\section{Theoretical model}

The particular theoretical model of this research is shown in Figure 1. where you can see how the organizational climate variable tries to measure labor productivity. The relationship is subject to verification in subsequent studies, it is only proposed as theoretical support.

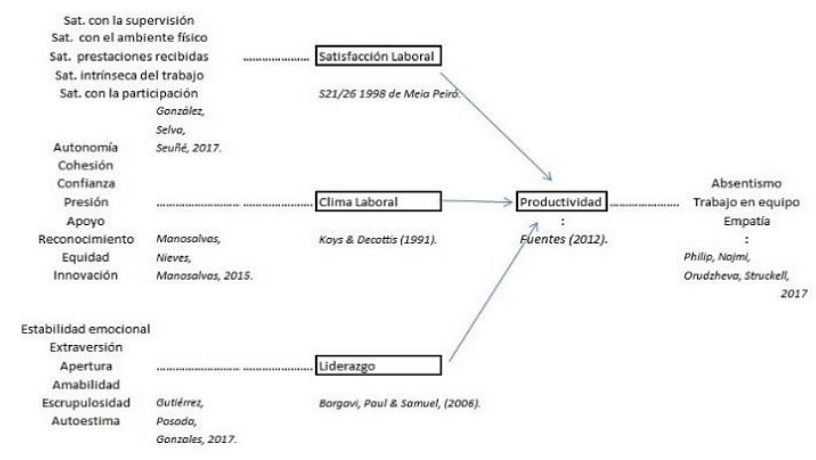

Figure 1 Particular theoretical model, subject to verification

Source: self made (2019)

\section{Method \\ Investigation}

The research is carried out by means of quantitative, non-experimental analysis with cross-section (Hernández, Fernández and Baptista, 2014; and Bernal, 2016).

\section{Variables Independent variable: Organizational
Climate}

Conceptual definition: It deals with the organizational commitment that lies in the sample of a direct impact of the attitudes of the employees, such as: the acceptance of goals, values and culture of the organization, less absenteeism and low turnover among others, (Betanzos Days and Peace Rodríguez, 2007).

Operational definition: The processes that affect the measurement of the work environment, such as: autonomy, cohesion, trust, pressure, support, recognition, equity and innovation (Koys \& Decottis 1991).

\section{Dependent variable: Productivity.}

Conceptual definition: Faisal \& Whyte, (2015) mentions that productivity is the amount of production per unit of input (labor) and in the field of construction is predominant. Durdyev and Mbachu (2011), say that productivity is strongly associated with the commercial feasibility that is indispensable for the understanding of the factors that positively affect the improvement of growth in this area, such as levels that lack focused knowledge.

Operational definition: The factors that affect the measurement of productivity, such as: absenteeism. teamwork and empathy, Fuentes (2012).

\section{Sociodemographic Variables}

The sociodemographic variables are: sex, age, job and schooling. 


\section{Measurement tools}

The Organizational Climate is measured with the instrument of Koys \& Decottis (1991) in a complete version of 40 items that evaluate eight dimensions: autonomy, cohesion, trust, pressure, support, recognition, equity and innovation; Likert scale from 1 to 5 is applied, with 5 being the highest rating.

While Labor Productivity is measured with the Fuentes instrument (2012) in the full version of 25 items with the following three dimensions: empathy, teamwork and absenteeism with the Likert scale from 1 to 5 , with 5 being the highest rating high.

\section{Participants (sample characteristics)}

50 instruments which belong to all the work areas of the Autonomous University of Guadalajara, of any age and sex is indifferent, by the type of non-probabilistic sampling for convenience (Hernández, Fernández and Baptista, 2014; and Bernal, 2016). The characteristics of the selected sample are detailed below (see table 1).

\begin{tabular}{|c|c|}
\hline $\begin{array}{c}\text { Sociodemographic } \\
\text { Variables }\end{array}$ & Sample Profile \\
\hline Age & Mean $=31$ years \\
\hline Gender & $\begin{array}{l}\text { Male }=28.30 \% ; \text { Female }= \\
71.70 \%\end{array}$ \\
\hline Scholarship & $\begin{array}{l}\text { High School }=100 \% ; \\
\text { Bachelor's degree }=93.20 \% ; \\
\text { Mastery }=12.97 \%\end{array}$ \\
\hline \multicolumn{2}{|l|}{ Work variables } \\
\hline Position & $\begin{array}{l}\text { Average controls }=87.20 \% \text {; } \\
\text { Management controls } \\
12.80 \%\end{array}$ \\
\hline
\end{tabular}

Table 1 Sample characteristics

Source: self made (2019)

\section{Process}

The method used to collect the information was through surveys carried out on paper with a total of 130 items on a Likert scale from 1 to 5, with 5 being the maximum score to be obtained. Divided into the two variables: organizational climate and productivity.

\section{Data analysis}

Non-experimental correlational-causal crosssectional quantitative research that allows obtaining results from an inferential statistical analysis.
The hypotheses will be tested using a model of structural equations, for which an instrument based on the above-mentioned methodology will be used. Pilotage: 50 instruments, reliability (Cronbach's alpha) and validity, (factor analysis). Hypothesis testing: 50 valid questionnaires through structural equations using R2, partial least squares test. Tools: Qualtrics, SPSS version 24, AMOS, EXCEL and Normality with Kolmogorov-Smirnoof. Statistical tests of reliability and validity of the instrument were performed, as well as descriptive statistics, normality tests and correlations between elements. The data is processed with the statistical software SPSS (Statistical Package for the Social Sciences) version 25 .

\section{Results and Discussion}

\section{Descriptive results}

In the present work, the various statistical tests were carried out to review the instruments of each of the variables: organizational climate and productivity, in relation to the work environment in general, the statistical tests validate the reliability and normality of each of the items in a $90 \%$, to finish in the productivity instrument, good tests are argued from $90 \%$ to $100 \%$. By dimension, the alpha starts and ends mentioned how many items were removed.

\begin{tabular}{|l|c|l|c|}
\hline \multicolumn{2}{|c|}{ Variable or Dimension } & \multicolumn{1}{c|}{ If the question is } \\
deleted & $\begin{array}{c}\text { New } \\
\text { alpha }\end{array}$ \\
\hline Work satisfaction & .947 & & .894 \\
\hline Sat. With the Supervision & .885 & If P.10 is deleted & \\
\hline $\begin{array}{l}\text { Sat. With the Physical } \\
\text { Environment }\end{array}$ & .805 & It is the best Alpha & \\
\hline Sat. Benefits Received & .758 & It is the best Alpha & \\
\hline Sat. Intrinsic of Work & .850 & It is the best Alpha & \\
\hline Sat. With the Participation & .731 & If P.9 is deleted & .793 \\
\hline Working environment & .911 & & \\
\hline Autonomy & .705 & If P.4 is deleted & .713 \\
\hline Cohesion & .832 & It is the best Alpha & \\
\hline Trust & .896 & If P.11 is deleted & .897 \\
\hline Pressure & .751 & If P.16 is deleted & .791 \\
\hline Support for & .904 & If P.25 is deleted & .918 \\
\hline Recognition & .584 & If P.30 is removed & .638 \\
\hline Equity & .808 & If P.34 is deleted & .890 \\
\hline Innovation & .882 & It is the best Alpha & \\
\hline Leadership & .803 & & \\
\hline Emotional stability & .806 & If P.27 is deleted & .823 \\
\hline Extraversion & .209 & If P.23 is deleted & .270 \\
\hline Opening & & & \\
\hline Amiability & .612 & If P.24 is deleted & .637 \\
\hline Conscientiousness & .616 & It is the best Alpha & \\
\hline Self esteem & .577 & If P.20 is removed & .589 \\
\hline Productivity & .942 & & \\
\hline Absenteeism & .858 & It is the best Alpha & \\
\hline I work in a team & .889 & It is the best Alpha & \\
\hline Empathy & .857 & It is the best Alpha & \\
\hline
\end{tabular}

Table 2 Descriptive statistics of the Cronbach Alpha Organizational Climate variable

Source: self made (2019) 
The following tables show each of the variables compared with a categorical variable that in this case is "sex" in the first table of each one, you can see the groupings of the results according to the items and the dimensions of each one, and In the second table of each variable the rotated variable component was applied, for which "Varimax" was helpful, it was rotated several times and the final results are obtained in this work.

Rotating component matrix.

\begin{tabular}{|c|c|c|c|c|c|c|c|c|}
\hline $\begin{array}{l}\text { ORGAIIAATIONA } \\
\text { CLIMATE - AUTONOMY }\end{array}$ & & & & & & 0.851 & .090 & \\
\hline $\begin{array}{l}\text { ORGANIZATIONAL } \\
\text { CLIMATE - AUTONOMY }\end{array}$ & 0.245 & 0.126 & 0.016 & -0.245 & 0.120 & 0.691 & -0.472 & -0.146 \\
\hline $\begin{array}{l}\text { ORGANIZATIONAL } \\
\text { CLIMATE - AUTONOMY } \\
3\end{array}$ & -0.064 & 0.281 & 0.168 & -0.038 & 0.696 & 0.403 & -0.003 & 0.081 \\
\hline $\begin{array}{l}\text { ORGANZATIONAL } \\
\text { CLIMATE - AUTONOMY }\end{array}$ & 0.301 & 0.516 & 0.169 & 0.052 & 0.255 & 0.175 & -0.062 & -0.418 \\
\hline $\begin{array}{l}\text { ORGANZATIONAL } \\
\text { CLIMATE - AUTONOMY } \\
\text { cI }\end{array}$ & 0.137 & 0.185 & 0.005 & -0.439 & 0.332 & 0.254 & -0.104 & -0.036 \\
\hline $\begin{array}{l}\text { ORGANZATIONAL } \\
\text { CLMATE-COHESION } 6\end{array}$ & -0.069 & 0.697 & 0.089 & -0.199 & 0.226 & 0.206 & -0.101 & -0.126 \\
\hline $\begin{array}{l}\text { ORGAIIATIIONAL } \\
\text { CLIMAT-COHESION } 7\end{array}$ & -0.051 & 0.841 & 0.247 & 0.064 & -0.012 & -0.217 & -0.078 & -0.063 \\
\hline $\begin{array}{l}\text { ORGANIZATIONAL } \\
\text { CLIMATE - COHESION } 8\end{array}$ & 0.102 & 0.799 & 0.085 & 0.204 & -0.087 & 0.071 & 0.207 & 0.089 \\
\hline $\begin{array}{l}\text { ORGANIZATIONAL } \\
\text { CLIMATE-COHESION } 9\end{array}$ & 0.183 & 0.620 & 0.173 & 0.194 & 0.034 & 0.298 & 0.392 & 0.072 \\
\hline $\begin{array}{l}\text { ORGANIZATIONAL } \\
\end{array}$ & 0.112 & 0.757 & -0.104 & -0.193 & 0.323 & -0.002 & -0.058 & 0.049 \\
\hline $\begin{array}{l}\text { ORGANIZATIONAL } \\
\text { CIMATE TRST } 11\end{array}$ & 0.755 & 0.003 & 0.239 & -0.009 & -0.089 & 0.169 & -0.040 & -0.098 \\
\hline $\begin{array}{l}\text { ORGANIZATIONAL } \\
\text { CLMATE-TLST } 12\end{array}$ & 0.765 & 0.031 & -0.048 & -0.073 & 0.061 & 0.223 & 0.193 & -0.004 \\
\hline ORGANZATIONAL & 0.762 & 0.082 & 0.037 & -0.053 & 0.101 & 0.156 & 0.067 & -0.165 \\
\hline 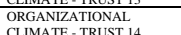 & 0.913 & -0.071 & 0.026 & -0.038 & 0.064 & 0.053 & 0.020 & 0.065 \\
\hline 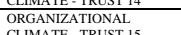 & 0.733 & 0.062 & 0.042 & 0.203 & 0.335 & -0.252 & 0.084 & -0.044 \\
\hline $\begin{array}{l}\text { ORGANIZATIINAL } \\
\text { CLIMATE - PRESSURE } 1\end{array}$ & 0.279 & 0.021 & 0.100 & 0.327 & -0.655 & -0.127 & -0.002 & -0.017 \\
\hline 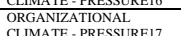 & 0.308 & 0.286 & 0.086 & 0.095 & 0.624 & -0.169 & 0.100 & 0.005 \\
\hline 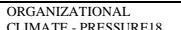 & -0.082 & 0.100 & 0.236 & 0.851 & -0.036 & 0.061 & -0.040 & -0.047 \\
\hline $\begin{array}{l}\text { ORGANZATIONAL } \\
\text { PITA }\end{array}$ & -0.200 & -0.069 & 0.005 & 0.863 & -0.002 & -0.136 & 0.048 & -0.079 \\
\hline $\begin{array}{l}\text { ORGANZZATIINAL } \\
\text { CLIMATE - PRESSURE20 }\end{array}$ & 0.050 & 0.116 & -0.176 & 0.646 & -0.063 & -0.242 & 0.050 & 0.440 \\
\hline 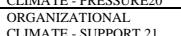 & 0.911 & 0.041 & 0.109 & -0.016 & 0.011 & -0.104 & -0.075 & 0.108 \\
\hline ORGANIZATIINANAL & 0.789 & -0.162 & 0.307 & -0.159 & 0.182 & -0.077 & -0.176 & 0.034 \\
\hline $\begin{array}{l}\text { ORGANIATIINAL } \\
\text { CLIMATE - SUPPORT } 23\end{array}$ & 0.790 & -0.204 & 0.274 & -0.167 & 0.012 & -0.047 & -0.257 & 0.057 \\
\hline $\begin{array}{l}\text { ORGANZATIONAL } \\
\text { CLIMATE - SUPPORT } 24\end{array}$ & 0.860 & 0.175 & 0.070 & -0.138 & -0.110 & 0.045 & 0.043 & 0.053 \\
\hline $\begin{array}{l}\text { ORGANIZATIINAL } \\
\text { CLIMATE - SUPPORT } 25\end{array}$ & 0.729 & 0.237 & -0.010 & 0.165 & -0.127 & 0.304 & -0.089 & -0.219 \\
\hline $\begin{array}{l}\text { ORGANIZATIONAL } \\
\text { CLIMATE } \\
\text { RECOGNITION } 26\end{array}$ & 0.440 & 0.339 & 0.136 & 0.323 & -0.223 & 0.019 & -0.267 & -0.060 \\
\hline $\begin{array}{l}\text { ORGANIZATIONAL } \\
\text { CLIMATE } \\
\text { RECGNTIION } 27\end{array}$ & -0.111 & 0.093 & -0.011 & 0.129 & 0.058 & -0.044 & 0.861 & 0.120 \\
\hline $\begin{array}{l}\text { ORGANIZTTIONAL } \\
\text { CLIMATE } \\
\text { RECGGNITION } 28\end{array}$ & 0.757 & 0.165 & 0.255 & 0.042 & -0.090 & 0.296 & 0.095 & 0.192 \\
\hline $\begin{array}{l}\text { ORGAIZZTIONAL } \\
\text { CLMATEGNITION } 29\end{array}$ & 0.402 & 0.373 & 0.504 & 0.047 & 0.019 & -0.063 & 0.072 & -0.119 \\
\hline $\begin{array}{l}\text { ORGANIZTIONAL } \\
\text { CLIMATE } \\
\text { RECGGNTION } 30\end{array}$ & 0.344 & -0.184 & 0.100 & -0.025 & 0.239 & 0.268 & -0.016 & 0.755 \\
\hline $\begin{array}{l}\text { ORGANIZATIONAL } \\
\text { CLIMATE - EQUITY } 31\end{array}$ & 0.714 & 0.419 & 0.002 & -0.126 & -0.055 & -0.188 & -0.086 & 0.252 \\
\hline $\begin{array}{l}\text { ORGANIZATIONAL } \\
\text { CLIMTE - EOUTTY } 32\end{array}$ & 0.798 & 0.227 & 0.167 & -0.100 & 0.162 & -0.187 & -0.084 & 0.155 \\
\hline $\begin{array}{l}\text { ORGANIZATIONAL } \\
\text { ORIMTE-EOUTY } 33\end{array}$ & 0.261 & 0.240 & 0.476 & 0.130 & -0.446 & -0.094 & 0.136 & 0.505 \\
\hline $\begin{array}{l}\text { ORGANIZATIONAL } \\
\text { OLIMTE-FUTY } 34\end{array}$ & 0.606 & -0.056 & -0.047 & -0.130 & -0.294 & -0.151 & 0.054 & -0.027 \\
\hline ATIONAL & 0.398 & -0.072 & 0.049 & -0.212 & -0.044 & -0.026 & 0.640 & -0.202 \\
\hline 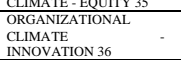 & 0.676 & 0.076 & 0.427 & 0.132 & -0.159 & -0.051 & 0.197 & 0.242 \\
\hline $\begin{array}{l}\text { ORGAIIATIIONAL } \\
\text { CLIMATE } \\
\text { INNOVATION } 37\end{array}$ & 0.231 & 0.077 & 0.871 & 0.009 & 0.118 & -0.140 & 0.096 & 0.032 \\
\hline $\begin{array}{l}\text { ORGANIZATIONAL } \\
\text { CLIMATE } \\
\text { INNOVATION } 38\end{array}$ & 0.229 & 0.162 & 0.826 & 0.098 & 0.006 & 0.049 & 0.049 & 0.017 \\
\hline $\begin{array}{l}\text { ORGANIZATIONAL } \\
\text { CLIMATE } \\
\text { INNOTATON } 39\end{array}$ & 0.729 & 0.290 & 0.351 & 0.012 & -0.130 & 0.047 & 0.146 & 0.287 \\
\hline $\begin{array}{l}\text { CLIMATE } \\
\text { ORGAIIIONAL } \\
\text { INNOVATION 40 }\end{array}$ & 0.721 & 0.079 & 0.379 & 0.025 & -0.019 & 0.134 & 0.306 & 0.276 \\
\hline
\end{tabular}

Table 3 Descriptive statistics of Organizational Climate dimension, component matrix

Source: self made (2019)
The previous table shows the groupings of the different items, which measure a common objective of each variable, for example: items 6 to 10 measure the cohesion dimension, the support dimension is also integrated, as well as the trust.

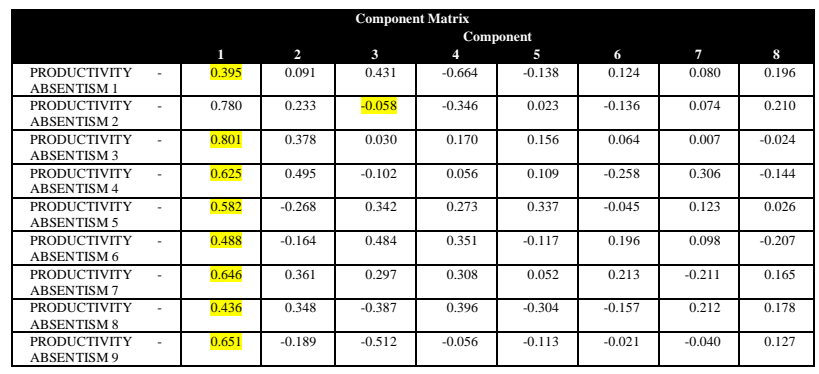

Table 4 Descriptive statistics of Productivity dimension, component matrix

Source: self made (2019)

\section{Normality tests}

The results of the data behaviors through kurtosis and asymmetry are shown below.

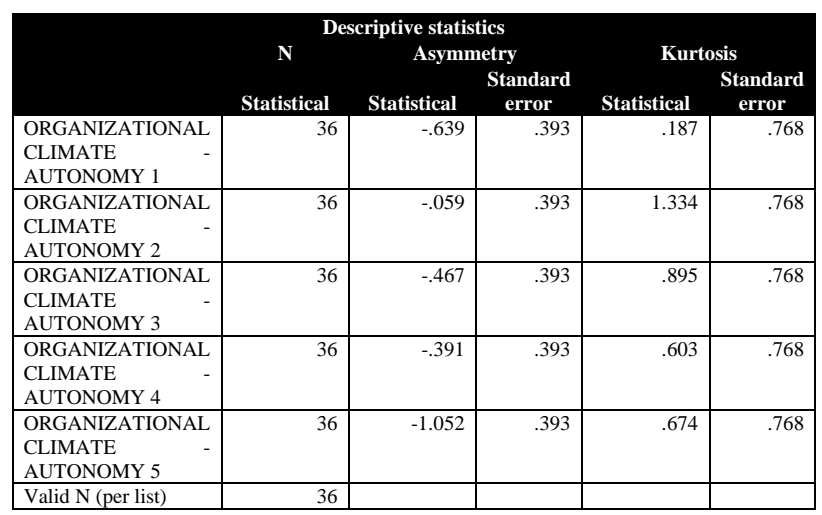

Table 5 Asymmetry and kurtosis calculations of the Organizational Climate dimension Source: self made (2019)

The results of the data behavior by means of Kolmogorov-Smirnov are shown below.

\begin{tabular}{|l|r|r|r|r|r|r|}
\hline & \multicolumn{9}{|c|}{$\begin{array}{l}\text { Kormality tests } \\
\text { Solmogorov-Smirnova }\end{array}$} & \multicolumn{2}{c|}{ Shapiro-Wilk } \\
\hline $\begin{array}{l}\text { Statistical } \\
\text { PRODUCTIVITY - TEAM }\end{array}$ & .289 & 36 & .000 & .680 & 36 & .000 \\
WORK 12 & .287 & 36 & .000 & .728 & 36 & .000 \\
\hline $\begin{array}{l}\text { PRODUCTIVITY - TEAM } \\
\text { WORK 13 }\end{array}$ & .267 & 36 & .000 & .776 & 36 & .000 \\
\hline $\begin{array}{l}\text { PRODUCTIVITY - TEAM } \\
\text { WORK 14 }\end{array}$ & .298 & 36 & .000 & .764 & 36 & .000 \\
\hline $\begin{array}{l}\text { PRODUCTIVITY - TEAM } \\
\text { WORK 15 }\end{array}$ & .297 & 36 & .000 & .742 & 36 & .000 \\
\hline $\begin{array}{l}\text { PRODUCTIVITY - TEAM } \\
\text { WORK 16 }\end{array}$ & .299 & 36 & .000 & .764 & 36 & .000 \\
\hline $\begin{array}{l}\text { PRODUCTIVITY - TEAM } \\
\text { WORK 17 }\end{array}$ & .252 & 36 & .000 & .797 & 36 & .000 \\
\hline $\begin{array}{l}\text { PRODUCTIVITY - TEAM } \\
\text { WORK 18 }\end{array}$ & .367 & 36 & .000 & .686 & 36 & .000 \\
\hline $\begin{array}{l}\text { PRODUCTIVITY - TEAM } \\
\text { WORK 19 }\end{array}$ & .355 & 36 & .000 & .655 & 36 & .000 \\
\hline $\begin{array}{l}\text { PRODUCTIVITY - TEAM } \\
\text { WORK 20 }\end{array}$ & & & & & & \\
\hline
\end{tabular}

Table 6 Kolmogorov-Smirnov calculations of the Productivity with teamwork dimension Source: self made (2019)

NAVARRO-HERNANDEZ, Ana Rosa \& CASTROVALENCIA, Alberto Merced. Productivity of the millennial generation in institutions of higher education. ECORFAN Journal-Republic of El Salvador. 2019 


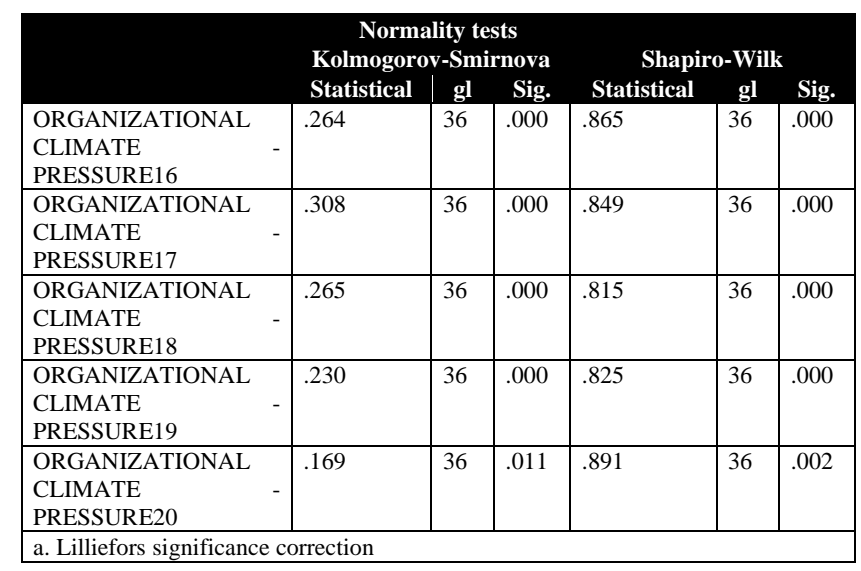

Table $7 \quad$ Kolmogorov-Smirnov calculations Organizational Climate dimension - Pressure Source: self made (2019)

\begin{tabular}{|c|c|c|c|c|c|c|}
\hline & \multicolumn{3}{|c|}{$\begin{array}{c}\text { Normality tests } \\
\text { Kolmogorov-Smirnova }\end{array}$} & \multicolumn{3}{|c|}{ Shapiro-Wilk } \\
\hline & Statistical & gl & Sig. & Statistical & gl & Sig. \\
\hline $\begin{array}{l}\text { ORGANIZATIONAL } \\
\text { CLIMATE - TRUST } 11\end{array}$ & .317 & 36 & .000 & .765 & 36 & .000 \\
\hline $\begin{array}{l}\text { ORGANIZATIONAL } \\
\text { CLIMATE - TRUST } 12\end{array}$ & .393 & 36 & .000 & .649 & 36 & .000 \\
\hline $\begin{array}{l}\text { ORGANIZATIONAL } \\
\text { CLIMATE - TRUST } 13 \\
\end{array}$ & .291 & 36 & .000 & .758 & 36 & .000 \\
\hline $\begin{array}{l}\text { ORGANIZATIONAL } \\
\text { CLIMATE - TRUST } 14\end{array}$ & .320 & 36 & .000 & .723 & 36 & .000 \\
\hline $\begin{array}{l}\text { ORGANIZATIONAL } \\
\text { CLIMATE - TRUST } 15\end{array}$ & .295 & 36 & .000 & .779 & 36 & .000 \\
\hline
\end{tabular}

Table 8 Kolmogorov-Smirnov calculations of the Organizational Climate dimension - Trust Source: self made (2019)

\begin{tabular}{|l|l|l|l|l|l|l|}
\hline \multicolumn{7}{|c|}{ Kormality tests } \\
\multicolumn{1}{|c|}{} & \multicolumn{1}{|c|}{ Kolmogorov-Smirnova } & \multicolumn{3}{c|}{ Shapiro-Wilk } \\
\hline $\begin{array}{l}\text { PRODUCTIVITY - } \\
\text { ABSENTISM 1 }\end{array}$ & .288 & 36 & .000 & .810 & 36 & .000 \\
\hline $\begin{array}{l}\text { PRODUCTIVITY - } \\
\text { ABSENTISM 2 }\end{array}$ & .313 & 36 & .000 & .762 & 36 & .000 \\
\hline $\begin{array}{l}\text { PRODUCTIVITY - } \\
\text { ABSENTISM 3 }\end{array}$ & .317 & 36 & .000 & .719 & 36 & .000 \\
\hline $\begin{array}{l}\text { PRODUCTIVITY - } \\
\text { ABSENTISM 4 }\end{array}$ & .279 & 36 & .000 & .765 & 36 & .000 \\
\hline $\begin{array}{l}\text { PRODUCTIVITY - } \\
\text { ABSENTISM 5 }\end{array}$ & .286 & 36 & .000 & .760 & 36 & .000 \\
\hline $\begin{array}{l}\text { PRODUCTIVITY - } \\
\text { ABSENTISM 6 }\end{array}$ & .285 & 36 & .000 & .790 & 36 & .000 \\
\hline $\begin{array}{l}\text { PRODUCTIVITY - } \\
\text { ABSENTISM 7 }\end{array}$ & .275 & 36 & .000 & .798 & 36 & .000 \\
\hline $\begin{array}{l}\text { PRODUCTIVITY - } \\
\text { ABSENTISM 8 }\end{array}$ & .323 & 36 & .000 & .758 & 36 & .000 \\
\hline $\begin{array}{l}\text { PRODUCTIVITY - } \\
\text { ABSENTISM 9 }\end{array}$ & .355 & 36 & .000 & .731 & 36 & .000 \\
\hline $\begin{array}{l}\text { PRODUCTIVITY - } \\
\text { ABSENTISM 10 }\end{array}$ & .267 & 36 & .000 & .762 & 36 & .000 \\
\hline $\begin{array}{l}\text { PRODUCTIVITY - } \\
\text { ABSENTISM 11 }\end{array}$ & .255 & 36 & .000 & .784 & 36 & .000 \\
\hline a. Corrección de significación de Lilliefors & & & \\
\hline
\end{tabular}

Table 9 Kolmogorov-Smirnov calculations of the Productivity dimension - Absenteeism

Source: self made (2019)

\section{Annexes}

Next, the 40 items of the instrument applied in the Organizational Climate variable are shown.

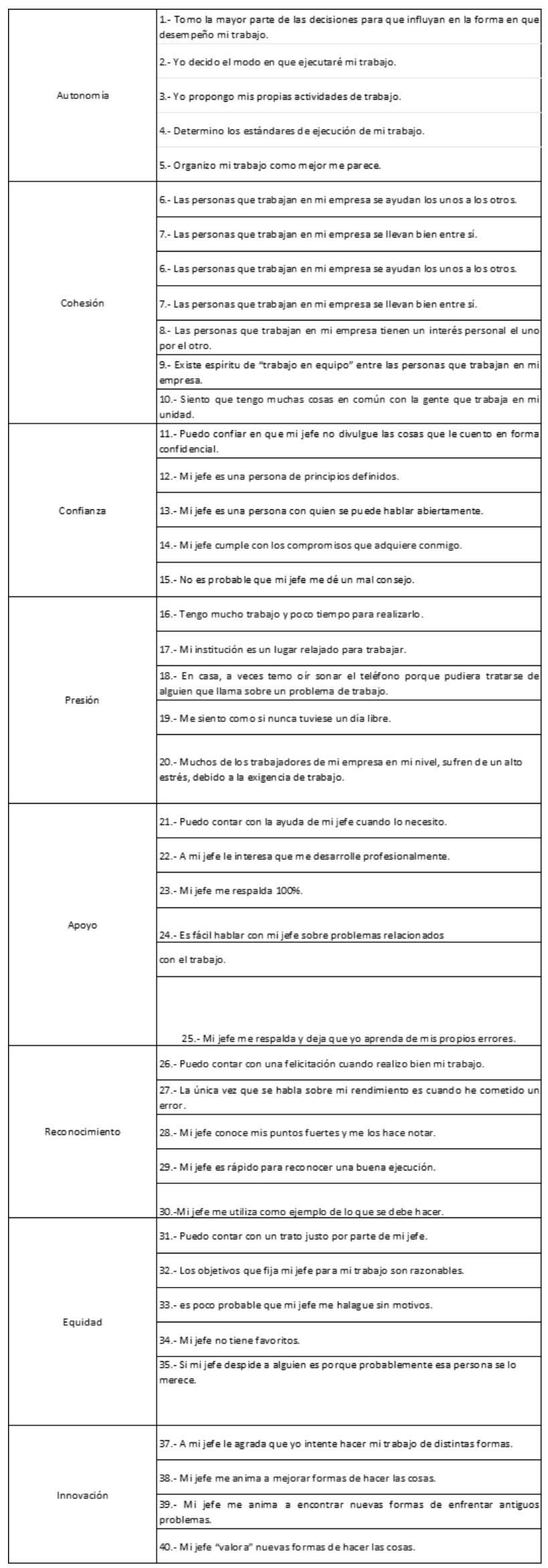

Table 1040 items of the instrument applied in the Organizational Climate variable

Source: self made (2019)

The 25 items of the instrument applied in the Productivity variable are shown below.

NAVARRO-HERNANDEZ, Ana Rosa \& CASTROVALENCIA, Alberto Merced. Productivity of the millennial generation in institutions of higher education. ECORFAN Journal-Republic of El Salvador. 2019 


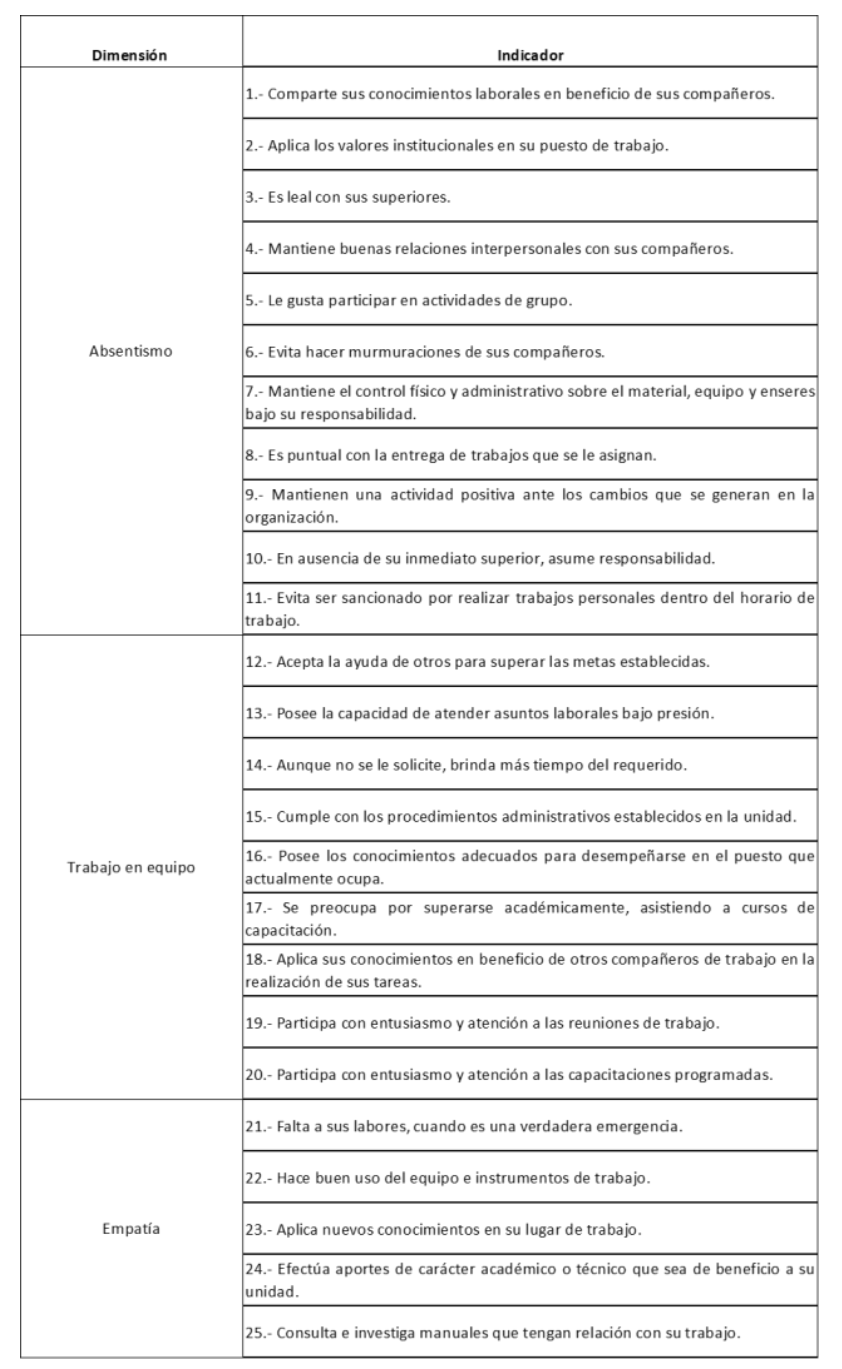

Table 1125 items of the instrument applied in the Productivity variable

Source: self made (2019)

\section{Acknowledgments}

Thanks to the coordinators of the UAG Administration Doctorate program, as well as to the professors who have taught the various subjects of the program, the participants in the implementation of the research instrument and my thesis director.

\section{Conclusions and recommendations}

In the present work you can see the different statistical tests that were applied, as well as their results in each one, definitely you must change some items that in each test are indicated, for example, in the Cronbach's Alpha it had to be run several times due because the final result did not increase, after one or even three times after running it the result improves, indicating that the reliability increases.
In the present work, the various statistical tests were carried out to review the instruments of each of the variables: organizational climate and productivity, in relation to the work environment in general, the statistical tests validate the reliability and normality of each of the items in a $90 \%$ and in the case of productivity, good evidence is argued from $90 \%$ to $100 \%$, however, in the thesis from which the instrument was obtained, statistics are not argued, that is; They are not so it is decided to propose gold model to measure productivity called "EFO" in which 16 items are presented which aim to measure productivity.

\section{References}

Bargavi, A. S. (2017). Intra- generational differences un the personality traits of millennial leaders in Indian IT sector . International Business Management, 1254-1262.

Bargavi, J. \&. (2016). Quantifying resilience in the personality of millennial leaders. Indian Journal of Science and Technology, 2-27.

Bargavi, S. \&. (2017). Resilience of millennial leaders in the Indian I.T. Industry. Journal of the Indian Academy of Applied Psychology, 211221.

Carrasco, D. \&. (2017). Eefectos del clima organizacional y los riesgos psicosociales sobre la felicidades en el trabajo. Contaduría y Administración, 2-14.

Chiang, N. M. (210). Compromiso del trabajador hacia su organización y la relación con el clima organizacional: un análisis de género y edad. . Panorama Socieconomico, 90-100.

Chiang, S. \&. (2007). Clima organizacional y satisfacción laboral en un establecimiento de salud estatal: hospital tipo 1. Theoria, 60- 76.

Chiang, S. \&. (2007). Clima y satisfacción laboral en instituciones públicas: adaptación y ampliación de in instrumento. . Conocimiento, innovación y emprendedores: camino hacia el futuro. , 3490-3507.

Fuentes. (2012). Satisfacción laboral y su influencia en la prodcutividad. Guatemala: Rafael Landívar. 
Meliá, M. S. (1990). Estructura factorial, fiabilidad y validez del cuestionario de satisfacción S21/26: un instrumento con formato dicotomico orientado al trabajo profesional. . Facultat de Psicologia, Universitat de Valencia. ,2-11.

Molina, P. \&. (2019). Estudio de cultura organizacional y satisfacción laboral en empresas comerciales. Ingenio y conciencia boletín científico de la escuela superior de la ciudad Sahagún. , 37-43.

Solanger. (2017). Percepción del entorno laboral de las enfermeras del área de salud de Lorca tras la implantación del programa de guías de práctica clínica centros comprometidos con la excelencia en cuidados. . Murcia, 1-3.

Solano. (2019). Satisfacción laboral en profesionales de enfermería. Investigasción en programas de enfermería , 53-62.

Zurita, R. Q. (2014). Compromiso organizacional y satisfacción laboral en una muestra de trabajadores de los juzgados de granada. Reidocrea, 17-25. 